\title{
THE IMPORTANCE OF WELL-BEING AND SATISFACTION WITH LIFE IN READING- COMPREHENSION AND MATHEMATICAL ABILITIES IN DEAF AND HEARING INDIVIDUALS
}

DOI: $\underline{\text { http://doi.org/10.26758/11.1.8 }}$

Yahir GONZALEZ (1), Diego-Oswaldo CAMACHO-VEGA (2)

(1)(2) Faculty of Medicine and Psychology, Universidad Autónoma de Baja California, USA

(2) E-mail: yahir.gonzalez@uabc.edu.mx

Address correspondence to: Diego Camacho, Universidad Autónoma de Baja California. Facultad de Medicina y Psicología. Calzada Universidad 14418, Parque Internacional Industrial Tijuana, 22390 Tijuana, B.C. Ph.: 664682 1233; E-mail: diego.camacho@uabc.edu.mx

\begin{abstract}
Objectives. The primary objective of this study is to evaluate if there are significant differences in reading-comprehension and mathematics between deaf and hearing individuals, identify if the level of Psychological Well-Being and Subjective Well-Being is related to higher mastery in readingcomprehension and mathematics, and finally, determine if self-perceived disadvantages in reading and mathematics by deaf individuals are related with their mastery in reading and mathematics tasks. Material and methods. A mixed-method was conducted including correlational and topological analysis of speech. The sample was constituted by 58 volunteers: five deaf individuals (age $M=28.4$ ) and 53 hearings (age $M=18.75$ ). Participants responded to the Satisfaction with Life Scale and the Ryff's Scales of Psychological Well-Being after solving the Adults Reading Evaluation and the Buenos Aires Mathematics test.

Results. Higher scores were found for the hearing group in reading and mathematics. No correlations were found between Satisfaction with Life and reading and mathematics neither between Psychological Well-Being and reading and mathematics for both groups. The qualitative analysis indicated that deaf individuals perceived no differences in their reading-comprehension and mathematics skills regarding hearings, but they scored significantly lower than hearings.

Conclusions. This study corroborated results from previous research about the differences in readingcomprehension and mathematical abilities between deaf and hearing individuals. This study identifies that differences between deaf and hearings might be more related to other factors such as the lack of awareness of difficulties in reading-comprehension and mathematics, while satisfaction with life and psychological well-being appears to be related to employment difficulties.
\end{abstract}

Keywords: Deaf, reading-comprehension, mathematics, psychological well-being, subjective wellbeing.

\section{Introduction}

According to the Organisation for Economic Co-operation and Development (OECD) cognitive abilities refer to "a set of thinking strategies that enable the use of language, numbers, reasoning and acquired knowledge, comprising verbal, non-verbal and high-order thinking skills" (OECD, 2019, p. 86). The OECD (2013) through the Programme for the International Assessment of Adult Competencies (PIAAC) identifies the cognitive abilities that are essential for adult life: Literacy, Numeracy, and Problem Solving in Technology-rich Environments (OECD, 2013) which are relevant in numerous social and working contexts and are necessary for participation and full 
integration in the labor market, education, and the social and civic development (Prada \& Rucci, 2016). This study focuses on the cognitive skills of reading-comprehension and mathematical abilities. Reading-comprehension is the capacity to understand, evaluate and apply written texts to develop personal skills, achieve goals and participate in society while mathematical ability is defined as the capacity to access, interpret and apply data and mathematical concepts in answer to overcome the diverse situations in daily life (OECD, 2013). Particularly, this research considers the manipulation of elements, logical-deductive reasoning, symbolic representation, and analytic reasoning as mathematics abilities (Cortada \& Macbeth, 2007).

Previous studies have analyzed both reading-comprehension and mathematical abilities based only on hearing individuals. Therefore, there is a need of assessing these abilities in vulnerable groups such as deaf individuals who are considered by the World Health Organisation (WHO, 2020) as people with profound hearing loss which implies very poor or null access to sound.

Studies that consider deaf-individuals are relevant because it has been found that deaf people perform low in reading tasks, being a clear minority who achieve a reading skill equivalent to the expected at the end of elementary education (Moreno-Pérez, Saldaña, \& Rodríguez-Ortiz, 2015). These differences can be explained in part by the differences in phonological processes between deaf and hearing individuals (Herrera, 2005; Kyle \& Cain, 2015; Moreno-Pérez et al., 2015; Wauters, Van Bon, \& Tellings, 2006). Additionally, deaf individuals who did not acquire sign language (SL) show structural differences compared with those who acquired previously the SL. The main differences consist in spoken language acquisition difficulties, as well as the limited linguistic experience including low access to lexical, syntax, semantics, speech as elements of language, and weak reading instruction processes implied in the level of reading and writing, which implies better achievement for deaf readers with the dominion of SL in reading and writing tasks. (Figueroa \& Rosa Lissi, 2005).

Similarly, previous research suggests that deaf individuals show lower performance than hearing in mathematics assignments (Andin, Rönnberg, \& Rudner, 2014; Bull, Blato-Valle, \& Fabich, 2006; Kelly, Lang, \& Pagliaro, 2003; Masataka, 2006; Pagliaro \& Ansell, 2012). It is considered that hearing loss and environments with little language stimulation influence low scores because they deprive deaf people of learning opportunities, a situation that reduces their exposition to early numerical concepts which consequently leads to a lack of the necessary elements for further mathematical learning, contributing to the difficulty that deaf individuals experience with arithmetical estimations when values should be accessed from symbols (Bull et al., 2011). That becomes more relevant considering the importance of mastering whole numbers and basic mathematical operation before starting fractional numbers (Mousley \& Kelly, 2017). Otherwise, Marschark, Morrison, Lukomski, Borgna and Convertino (2013) point out that deaf signers have some advantage in the visual-spatial working memory, a condition that translates into a better development in visual mathematical problems but only in schematization and organization, not in mathematical processing itself compared to non-signer equals and hearing peers.

In addition to the lack of educational opportunities, some evidence about the association between cognitive and life satisfaction has suggested a close correlation (Enkvist, Ekström, \& Elmståhl, 2013). In the same way, prior evidence suggested a significant correlation between psychological well-being and cognitive skills (Llewellyn, Lang, Langa, \& Huppert, 2008) but research about these topics is not yet clear in deaf groups.

Deaf people are known to be at much greater risk of developing psychological problems (Gascon-Ramos, 2007) but the relationship between psychological issues and educational problems in this population is still unclear. Psychological Well-being has become relevant due to its relationship with facts as employments or happiness, the ease or difficulty to find employment, academic performance, and social participation, being more notorious in female and student population (Moreta-Herrera, López-Calle, Gordón-Villalba, Ortíz-Ochoa, \& Gaibor-González, 2018; Wiklunda, Nikolaevb, Shirc, Food, \& Bradleye, 2019). There are two broad lines of study for Wellbeing in Psychology: a) psychological well-being, based on the concept of eudaimonia which is 
linked to the ideal of happiness, (Padrós \& Medina, 2015) b) subjective well-being, based on the concept of hedonism, related to satisfaction and avoidance of suffering (Moreta, Gaibor, \& Barrera, 2017; Zubieta \& Delfino, 2010), both included inside the framework of the Positive Mental Health.

In this study the concept of Psychological Well-Being (PWB) refers to what makes us feel alive and authentic, helping us to grow as individuals. Therefore, it includes social and individual indicators including the evaluation that people make about their circumstances and function in society, the way they face their conditions in life, the reach of success, and personal development.

Subjective Well-Being (SWB) focalizes the perception that people have of their current condition (Cárdenas et al., 2012; Moreta et al., 2017; Padrós \& Medina, 2015) and asks how and why people can perceive their life positively (Moreta et al., 2017). Subjective well-being is compound by cognitive and emotional elements (positive or negative emotions). Its cognitive element is the satisfaction with life defined as a global opinion that the individual has about his life comparing his overall success versus his expectations (Cabañero et al., 2004; Cárdenas et al., 2012).

Based on the beforehand explanation, the present study aims to evaluate if there are significant differences in reading-comprehension and mathematical abilities between deaf and hearing individuals, identify if the level of Psychological Well-Being and Subjective Well-Being is related to higher mastery in reading-comprehension and mathematics, and finally, determine if a selfperceived disadvantage in reading and mathematics by deaf individuals is related with their mastery in reading and mathematics tasks.

\section{Material and methods}

A mixed method was applied with a correlational focus for quantitative aspects of the study and a transversal topological analysis of speech for qualitative aspects (the qualitative approach was only considered for the deaf group). Due to the lack of instruments to measure cognitive skills, psychological well-being, and satisfaction with life, this study searches to obtain objective and subjective/self-report measures of cognitive abilities of reading comprehension and mathematical ability.

Sample

The study was conducted on a sample of 58 volunteers from a Mexican population that accepted to participate in the study after signing the informed consent. Then, two groups were formed. The first group corresponded to five deaf individuals (DG) (3 females and 2 males) (DG mean age $M=28.4$ ), all bilateral, profound, prelingual deaf who reached university education and practiced Sign Language (specifically the Mexican Sign Language or MSL). This group was selected with the collaboration of an SL translator. None of the participants had an auxiliary implant and all of them spoke SL. The second group was formed by 53 hearing participants (HG mean age $=19$ ) where 67\% were females.

\section{Instruments}

All participants completed the Adults Reading Evaluation test (ELA) (Matute, Chamorro, González, Ventura, \& Parra, 2015), the Buenos Aires Mathematics Test (TMBA) developed by Cortada and Macbeth (2007), the Satisfaction with Life Scale (SWLS) developed by Diener, Emmons, Larsen and Griffin (1985), and the Ryff's Scales of Psychological Well-Being (SPWB) (Díaz et al., 2006). An MS PowerPoint presentation with video-recordings supported by the explanation of a Sign Language interpreter was delivered for the deaf group (DG) during the whole evaluation. Only the reading passage from ELA was not translated to SL. Following the recommendations of Kyle and Cain (2015) who suggest that deaf individuals have difficulties 
understanding abstract or poorly concrete contents, all the scales were reduced to 3 choices (Yes $=1$, I don't know $=2$, no $=3$ ) for the DG.

The ELA is an instrument that assesses reading precision, speed, and comprehension. For this study, we focused on the comprehension dimension of the instrument using the reading passage provided by the instrument. To test mathematics ability, a 10-items adaptation of the TMBA was administrated. This questionnaire evaluates the manipulation of elements; logical-deductive reasoning; symbolic representation; and analytic reasoning. TMBA was reduced from 50 to 10 items choosing the items with higher correlation indicated by Cortada and Macbeth's study (2007) (items $2,13,18,22,25,28,34,38,39,49$ from the original 50-item questionnaire). Each one related to one of the dimensions assessed in the test, namely: simple arithmetic calculations (item 4); operation with decimals (items 1, 5, and 6); proportions, percentages, and rule of three (items 3 and 10); algebraic solving (items 8 and 7); and geometry problems (items 2 and 9).

The SWLS is a 5-item scale to evaluate the global judgment about self-perceived satisfaction with life.

Finally, the SPWB is a 29-items scale to measure six factors of Psychological Well-Being: 1) Self-acceptance, 2) Autonomy, 3) Positive Relationships, 4) Environmental Mastery, 5) Purpose in Life and 6) Personal Growth.

\section{Procedure}

Both groups completed the full evaluation in the faculty computer laboratory. For the assessment of DG the SL interpreter helped to locate the participants giving them the instructions orally. Complementary, an MS PowerPoint presentation was shown on the same screen. For the HG sample, the formulary was given with no modifications. Cronbach-alpha values for each scale are shown in Table 1.

\section{Quantitative analysis}

A descriptive analysis of all the natural scores of each sub-test in the formulary was done, then an exploratory analysis of the data distribution was calculated for each group. After that, significant differences between both groups were examined in each sub-test of the formulary using the Mann-Whitney $U$ test for independent non-parametrical samples, and finally, the correlation coefficients were obtained with Pearson's $r$ in the DG because of the normal distribution of data showed from the Shapiro-Wilk test, while the Spearman's rank correlation coefficient $r_{s}$ was applied in the HG due to the non-normal distribution of data in this group.

\section{Qualitative analysis}

Deaf participants were interviewed with a semi-structured interview supported by the LS. Then, a topological analysis of speech was conducted. This process was audio-recorded and subsequently, the information was analyzed using the ATLAS.ti 8 software.

\section{Results}

\section{Quantitative results}

To determine significant differences between groups, the Mann-Whitney's $U$ was calculated for the whole set of tests (Table 1). 


\section{Table 1}

Differences between groups and reliability by scale

\begin{tabular}{lcccccc}
\hline Scales & Groups & $\boldsymbol{M}$ & $\boldsymbol{S D}$ & $\boldsymbol{U}(\mathbf{5 6})$ & $\boldsymbol{p}$ & $\begin{array}{c}\text { Cronbach- } \\
\text { alpha }\end{array}$ \\
\hline \multirow{2}{*}{ SWLS } & DG & 12.20 & 2.59 & 122.50 & .780 & .65 \\
& HG & 12.26 & 2.94 & & & .77 \\
\multirow{2}{*}{ ELA } & DG & 1.60 & 1.14 & 14.500 & $<.001$ & .62 \\
& HG & 5.89 & 2.09 & & & .50 \\
TMBA & DG & 2.20 & 1.48 & 21.000 & $<.001$ & .33 \\
& HG & 5.21 & 1.69 & & & .35 \\
\multirow{2}{*}{ SPWB } & DG & 76.20 & 5.07 & 4.00 & $<.001$ & .61 \\
& HG & 62.66 & 6.81 & & & .74 \\
\hline
\end{tabular}

Notes.

SWLS = Satisfaction with Life Scale

ELA = Reading Evaluation for AdultsEvaluación de Lectura para Adultos

TMBA = Test de Matemáticas Buenos Aires

SPWB $=$ Ryff's Psychological Well-Being Scales

As is shown in Table 1, the results indicated significant differences $(p<.01)$ between the DG and $\mathrm{HG}$ for ELA $U(56)=122$, and TMBA $U(56)=21$. For further analysis of our data, we compare all items of the TMBA between DG and HG. We found significant differences for items 9 (geometry problems scale), and item 10 (proportions, percentages, and rule scale). Meanwhile, significantly higher values were found for the DG in the SPWB scale $U(56)=4, p<.01$.

To achieve the second objective of this research which tried to determine if readingcomprehension and mathematical abilities are correlated with Psychological Well-Being, the Spearman's Rank-Order Correlation was calculated for HG while the Pearson's Product-Moment Correlation test was conducted for DG due to the distribution of the dataset.

For DG, no significant correlation $(p>.05)$ was found between SWLS and readingcomprehension as well as no significant correlation was found between SWLS and mathematicalabilities. Similar results were found for HG (Table 2).

Table 2

Correlations between ELA, TMBA, and SWLS, SPWB

\begin{tabular}{lccccc}
\hline & & \multicolumn{2}{c}{ SWLS } & \multicolumn{2}{c}{ SPWB } \\
\cline { 3 - 6 } & & Coeficient & $\boldsymbol{p}$ & Coeficient & $\boldsymbol{p}$ \\
\cline { 3 - 6 } ELA & DG & .81 & .09 & .33 & .60 \\
& HG & -.20 & .14 & -.00 & .99 \\
\multirow{2}{*}{ TMBA } & DG & .27 & .66 & .41 & .50 \\
\cline { 3 - 5 } & Note. $r_{s}$ Spearman was calculated for HG, whereas r Pearson for DG. & &
\end{tabular}




\section{Qualitative results}

To determine if self-perceived disadvantages in deaf individuals are related to results in reading-comprehension and mathematics tasks for deaf individuals, the qualitative analysis indicated that deaf individuals self-perceive their cognitive skills as high (Table 3 shows the inductive codification based on the theoretical framework, the analytic categories defined as high and low and examples of unit analysis). Individuals from the DG do not self-perceive differences in reading and mathematics skills regarding hearings. They expressed that their SPWB and their SWLS is affected by inequalities in job opportunities more than disadvantages in the analyzed cognitive skills. Besides, learning for life, family, friends, and healthy social relations were considered important factors related to their PWB and SWLS. While participants referred to positive high levels regarding the six factors evaluated by the SPWB. Finally, deaf individuals experience a lack of social inclusion which has resulted in difficulties to get hired and complications to obtain autonomy in their life.

\section{Table 3}

Matrix of codification and examples

\begin{tabular}{|c|c|c|c|}
\hline \multicolumn{2}{|c|}{$\begin{array}{l}\text { Inductive } \\
\text { codification }\end{array}$} & Analytic categories & Analysis unit (examples) \\
\hline $\mathrm{RCA}$ & $\begin{array}{l}\text { Declared } \\
\text { Reading } \\
\text { comprehension } \\
\text { ability }\end{array}$ & $\begin{array}{l}\text { High: Between } 70-100 \text { points on } \\
\text { a } 0-100 \text { scale. } \\
\text { Low: Between } 0-50 \text { points on a } \\
0-100 \text { scale. }\end{array}$ & $\begin{array}{c}\text { "80" - A } \\
\text { "40-45" - C }\end{array}$ \\
\hline MA & $\begin{array}{l}\text { Declared } \\
\text { mathematical } \\
\text { ability }\end{array}$ & $\begin{array}{l}\text { High: Between } 70-100 \text { points on } \\
\text { a } 0-100 \text { scale. } \\
\text { Low: Between } 0-50 \text { points on a } \\
0-100 \text { scale. }\end{array}$ & $\begin{array}{l}\text { "90" - B } \\
" 50 "-A\end{array}$ \\
\hline \multirow{3}{*}{ PWB } & \multirow{3}{*}{$\begin{array}{l}\text { Psychological } \\
\text { well-being }\end{array}$} & $\begin{array}{l}\text { Range between } 70-100 \text { points on } \\
\text { a } 0-100 \text { scale. }\end{array}$ & "80-90" - A \\
\hline & & $\begin{array}{l}\text { The participant relates certain } \\
\text { elements with his/her own PWB }\end{array}$ & $\begin{array}{l}\text { "Having a job, family well-being, } \\
\text { social relationships, that would make } \\
\text { my life better" - A. }\end{array}$ \\
\hline & & $\begin{array}{l}\text { The participant declares their } \\
\text { interest in autonomy in their life } \\
\text { or give example related to } \\
\text { autonomy in their life. }\end{array}$ & "I’m looking to be autonomous" - A. \\
\hline \multirow{3}{*}{ SWB } & \multirow{3}{*}{$\begin{array}{l}\text { Subjective } \\
\text { Well- Being }\end{array}$} & $\begin{array}{l}\text { The participant relates certain } \\
\text { elements with his/her own SWB }\end{array}$ & $\begin{array}{l}\text { "When you have a good job and go } \\
\text { ahead that is satisfaction" - B. }\end{array}$ \\
\hline & & & \\
\hline & & $\begin{array}{l}\text { Participants relate the role of } \\
\text { their job in their SWB }\end{array}$ & $\begin{array}{l}\text { "Obviously when you have a good job, } \\
\text { and the salary is good your satisfaction } \\
\text { with life" - B. }\end{array}$ \\
\hline IEA & $\begin{array}{l}\text { Influence of the } \\
\text { environment on } \\
\text { self-esteem }\end{array}$ & $\begin{array}{l}\text { Understand sentences where is } \\
\text { evident the feeling of inferiority } \\
\text { related to self-esteem, self- } \\
\text { image, etc. }\end{array}$ & $\begin{array}{l}\text { "Hearing people always will be higher } \\
\text { than us in advantage with deaf people" } \\
- \text { B. }\end{array}$ \\
\hline
\end{tabular}




\begin{tabular}{|c|c|c|c|}
\hline \multicolumn{2}{|c|}{$\begin{array}{l}\text { Inductive } \\
\text { codification }\end{array}$} & \multirow{2}{*}{$\begin{array}{l}\text { Analytic categories } \\
\text { Participants give examples } \\
\text { about how they have shown } \\
\text { resilience. }\end{array}$} & \multirow{2}{*}{$\begin{array}{l}\text { Analysis unit (examples) } \\
\text { "Is about awake and go ahead in life, } \\
\text { there are deaf people who do not accept } \\
\text { it and deaf people who accept it. It is } \\
\text { about your attitude" - C. }\end{array}$} \\
\hline & & & \\
\hline LPWB & $\begin{array}{l}\text { Learning as an } \\
\text { important } \\
\text { element in } \\
\text { his/her } \\
\text { psychological } \\
\text { well-being }\end{array}$ & $\begin{array}{l}\text { Participants relate the learning } \\
\text { of how an important factor for } \\
\text { PWB. }\end{array}$ & $\begin{array}{l}\text { "Based on many mistakes and lessons } \\
\text { learned, I have practiced and developed } \\
\text { my quality of life" - B. }\end{array}$ \\
\hline PREM & $\begin{array}{l}\text { Problems } \\
\text { related to the } \\
\text { environment } \\
\text { where he is part } \\
\text { of a minority. }\end{array}$ & $\begin{array}{l}\text { Participants refer to a lack of } \\
\text { inclusion explaining the } \\
\text { situation of their own life. }\end{array}$ & $\begin{array}{l}\text { "I do not declare I'm deaf until the } \\
\text { recruiter calls me to know my perfect } \\
\mathrm{CV} \text {, during the interview they know } \\
\text { about my reality. I do not declare I'm } \\
\text { deaf because they will say no" - B. } \\
\text { "I have my degree, but I will search } \\
\text { everywhere because they tell me no } \\
\text { because I'm a deaf woman" - A. }\end{array}$ \\
\hline
\end{tabular}

\section{Discussions}

According to the obtained results, there is evidence to state that the hearing group performed significantly better than deaf individuals on reading-comprehension and mathematical tasks in line with results from Kyle and Cain (2015), Wauters et al. (2006), Herrera (2005), Moreno et al. (2015), and Figueroa and Rosa Lissi (2005). Considering that reading and mathematics are one of the most important problems in education for the Mexican population (i.e. Mexico was ranked below the average in the PISA evaluation in both, reading and mathematics) (OECD, 2018), the fact of low mastery in these abilities in hearing population implies that the problem for deaf individuals might be a very important issue to consider in future research and educational policies.

The reason for the differences in performance between hearing and deaf individuals is currently unclear but the researchers agree with the hypothesis that the early development of language has a profound impact (Faletty, 2016; Fontané-Ventura, 2005; Myklebust, 1971). Sign language could settle the basis of oral language acquisition (ex. Spanish, English, etc.) (Herrera, 2005). Andin et al. (2014) and Bull et al. (2006) found that oral-phonologic knowledge influences multiplication tasks, underlining the importance of early development of language, being broadly evident in deaf individuals. Nevertheless, we did not consider when sign language was acquired by deaf individuals, we cannot assume this suggestion until we develop more research considering this factor.

Particularly, comparing all items of the TMBA, our analysis suggests differences between DG and HG in the proportions, percentages, and rule scale, as well as in the geometry problems scale. Consequently, future work should therefore include measurements to prove whether these factors are indeed significantly different.

It is important to note that the problem in reading and mathematics is hard in the entire hearing population in our country but unfortunately no data is available about deaf individuals. The fact of lower mastery in reading and mathematics could express different issues. For example, Hernández-Ontiveros and Camacho-Vega (2020) suggested that our educational system does not attempt to integrate deaf students. It avoids hearing loss students to develop oral skills in addition to a lack of development of the sign language since early childhood (Okada et al. 2015). Based on this 
asseveration, the analysis of reading and math solving problems between deaf and hearing individuals implies some difficulties mainly based on the context of the education received by deaf individuals. Another important factor to understand disadvantages in reading and mathematics in deaf individuals is the role of teachers in the educational processes. First, according to Kelly et al. (2003), teachers must have certificates. In higher education is common in our country that teachers demonstrate experience in their field before giving courses, but these experiences should indicate certification in pedagogical strategies for reading and mathematics, even more, when teaching deaf individuals. Kelly et al. (2003) also suggested that teachers should focus more on tasks which require analytical strategies and cognitively challenging problem rather than on task involving surface cues, language comprehension, and exercise drills for deaf students.

Moreover, results from the qualitative analysis indicated that deaf individuals do not perceive their reading and mathematics skills as low, but they obtained significantly lower scores in both tasks regarding hearings. This is a highlight proposed by our research because it might imply that deaf individuals may not be aware of cognitive differences compared to hearings. Thus, this lack of awareness about their difficulty in addition to the lack of opportunities in education might be an important approach for future research. It is necessary to create social and political awareness about the inclusion of deaf individuals in similar educational and adequate support such as sign language in their early years to create similar opportunities between deaf and hearings and create adequate strategies for better cognitive development.

Even deaf individuals referred not to have difficulties in the cognitive skills analyzed, they indicated another important disadvantage regarding hearings. Deaf individuals referred that employment is an important factor for their psychological well-being and satisfaction with life, ranked as the most important element followed by family-friends' relationships. They indicated that these disadvantages are more related to the fact of being deaf individuals rather than their abilities or experience for the job solicited. Further research is needed to understand the role of hiring difficulties in deaf individuals because it was not the objective of this study. Besides, our results suggested significant differences in SPWB between DH and HG but a deep analysis is needed to understand more about these differences.

Additionally, deaf individuals face several problems in their learning process that hearing people do not experience. This study focused on deaf individuals who reached an undergraduate level obtained at a university or technical degree and results evince that there is a lack of institutional consideration about deaf's difficulties to understand sentences with complex grammar structure, including abstract or not concrete sentences (Kyle \& Cain, 2015).

Finally, this study had some limitations. First. The voluntary integration of the deaf community could respond to a lack of social integration. This research indicates there is still a lot of work to do before inviting deaf people to participate in research studies about their condition. For this reason, our sample should be increased to obtain more reliable results.

\section{Conclusions}

In conclusion, this study supports research about the differences between readingcomprehension and mathematics in hearing and deaf individuals. It appears that certainly, deaf individuals develop lower than hearing individuals in reading and mathematics tasks. This study considered samples from deaf and hearing individuals with higher education studies to avoid bias based on educational level. Therefore, the paired-samples considering grade can reduce the bias of knowledge and abilities in both groups. Thus, the differences were significantly lower for deaf individuals and results suggest that educational level is not a factor that explains per se the differences between groups.

Second, no evidence of correlation based on the statistical analysis was found between cognitive abilities and psychological well-being or between cognitive abilities and satisfaction with 
life, but the qualitative analysis indicated an important finding: deaf individuals do not perceive difficulties in reading and mathematics which is not congruent with the results obtained in the tasks, suggesting a lack of awareness about their abilities.

If well, reading and mathematics abilities appear to be of no significances for deaf individuals in their psychological well-being and satisfaction with life, the most important factor related to their SPWB and SWLS appears to be the lack of job opportunities.

Finally, this study fills the need to propose instruments to measure the well-being and subjective well-being in deaf individuals showing that the SPWB and the SWLS are highly correlated questionnaires and its application fits in both samples for furthermore studies, in addition to the evaluation of reading and mathematics abilities using the ELA and the TMBA test respectively.

\section{Acknowledgments}

We would like to thank the Universidad Autónoma de Baja California for all the facilities provided and to Sara Rivera for her valuable help translating to MLS all the necessary content for the deaf-individual participants and supporting them during all the study. Additionally, we would like to thank Maria Guadalupe Delgadillo for helping us to develop the qualitative analysis of this research.

\section{Abbreviations}

$\begin{array}{ll}\text { DG } & \text { Deaf Group } \\ \text { HG } & \text { Hearing Group } \\ \text { SWLS } & \text { Satisfaction with Life Scale } \\ \text { ELA } & \text { Reading Evaluation for Adults } \\ \text { TMBA } & \text { Test de Matemáticas Buenos Aires } \\ \text { SPWB. } & \text { Ryff's Psychological Well-Being Scales } \\ \text { PWB } & \text { Psychological Well-Being } \\ \text { RCA } & \text { Declared Reading comprehension ability } \\ \text { MA } & \text { Declared mathematical ability } \\ \text { PWB } & \text { Psychological well-being } \\ \text { SWB } & \text { Subjective Well- Being } \\ \text { IEA } & \text { Influence of the environment on self-esteem } \\ \text { LPWB } & \text { Learning as an important element in his/her psychological well-being } \\ \text { PREM } & \text { Problems related to the environment where he is part of a minority. }\end{array}$

\section{References}

1. Andin, J., Rönnberg, J., \& Rudner, M. (2014). Deaf signers use phonology to do arithmetic. Learning and Individual Differences, 32, 246-253. doi: https://doi.org/10.1016/j.lindif.2014.03.015

2. Bull, R., Blato-Valle, G., \& Fabich, M. (2006). Subitizing, magnitude representation, and magnitude retrieval in deaf and hearing adults. The Journal of Deaf Studies and Deaf Education, 11(3), 289-302. doi: https://doi.org/10.1093/deafed/enj038

3. Bull, R., Marschark, M., Sapere, P., Davidson, W. A., Murphy, D...Nordmann, E. (2011). Numerical estimation in deaf and hearing adults. Learning and Individual Differences, 21(4), $453-$ 457. doi: 10.1016/j.lindif.2011.02.001

4. Cabañero, M. J., Richart, M., Cabrero, J., Orts, M. I., Reig, A...Tosal, B. (2004). Fiabilidad y validez de la escala de satisfacción con la vida de Diener en una muestra de mujeres embarazadas y puérperas [Reliability and validity of the Diener`s scale in pregnant and post-partum women]. 
Psicothema, 16(3), 448-455. Retrieved December 20, 2020 from http://www.psicothema.com/pdf/3017.pdf

5. Cárdenas, M., Barrietos, J., Bilbao, A., Páez, D., Gómez, F...Asun, D. (2012). Estructura factorial de la escala de satisfacción con la vida en una muestra de estudiantes universitarios chilenos [Factorial structure of the satisfaction with life scale in higher education in Chilean university students]. Revista Mexicana De Psicología, 29(2), 157-164. doi: 10.29365/rpcc.20181207-70

6. Cortada de Kohan, N., \& Macbeth, G. (2007). Construcción de un test de matemáticas para adolescentes y adultos [Development of a mathematics test for adolescents and adults]. Interdisciplinaria, 24(1), 43-64. Retrieved December 21, 2020 from https://www.researchgate.net/publication/26485626

7. Díaz, D., Rodríguez-Carvajal, R., Blanco, A., Moreno-Jiménez, B., Gallardo, I., Valle, C., ...van Dierendonck, D. (2006). Adaptación española de las escalas de bienestar psicológico de Ryff [Spanish adaptation of the Ryff's well-being scales]. Psicothema, 18(3), 572-577.

8. Diener, E., Emmons, R. A., Larsen, R. J., \& Griffin, S. (1985). The satisfaction with life scale. Journal of personality assessment, 49(1), 71-75. Retrieved December 18, 2020 from http://www.psicothema.com/pdf/3255.pdf

9. Enkvist, A., Ekström, H., \& Elmståhl, S. (2013). Associations between cognitive abilities and life satisfaction in the oldest-old. Results from the longitudinal population study Good Aging in Skåne. Clinical Interventions in Aging, 845. https://doi.org/10.2147/CIA.S45382

10. Faletty, P. (2016). La importancia de la detección temprana de la hipoacusia [The importance of early detection of loss hearing]. Revista médica clínica Las Condes, 27(6), 745-752. doi: 10.1016/j.rmclc.2016.11.005

11. Figueroa, V., \& Rosa Lissi, M. (2005). La lectura en personas sordas: Consideraciones sobre el rol del procesamiento fonológico y la utilización del lenguaje de señas [Reading in deaf persons: Considerations about the role of phonological processing and the use of the sign language]. Estudios pedagógicos, 31(2), 105-119. doi: 10.4067/S0718-07052005000200007

12. Fontané-Ventura, J. (2005). Déficit auditivo. Retraso en el habla de origen audígeno [Delay in speech from a hearing origin]. Rev Neurol, 40(1), 25-37. doi: 10.33588/rn.41S01.2005388

13. Gascon-Ramos, M. (2008). Wellbeing in deaf children: A framework of understanding. Educational and Child Psychology. 25, 57-71. Retrieved January, 2021 from https://www.bps.org.uk/publications/educational-child-psychology

14. Hernández-Ontiveros, A. D., \& Camacho-Vega, D.-O. (2020). Academic Success Between Disabling Hearing Loss and Hearing Students in Upper-Secondary: An Inclusive Classroom. Postmodernism Problems, 10(3), 351-363. https://doi.org/10.46324/PMP2003351

15. Herrera, V. (2005). Habilidad lingüística y fracaso lector en los estudiantes sordos. Estudios pedagógicos, 31(2), 121-135. doi: http://dx.doi.org/10.4067/S0718-07052005000200008

16. Kelly, R. R., Lang, H. G., \& Pagliaro, C. M. (2003). Mathematics word problem solving for deaf students: A survey of practices in grades 6-12. Journal of deaf studies and deaf education, 8(2), 104-119. doi: 10.1093/deafed/eng007

17. Kyle, F. E., \& Cain, K. (2015). A comparison of deaf and hearing children's reading comprehension profiles. Topics in language disorders, 35(2), 144-156. doi: 10.1097/TLD.0000000000000053

18. Llewellyn, D. J., Lang, I. A., Langa, K. M., \& Huppert, F. A. (2008). Cognitive function and psychological well-being: Findings from a population-based cohort. Age and Ageing, 37(6), 685689. https://doi.org/10.1093/ageing/afn194

19. Marschark, M., Morrison, C., Lukomski, J., Borgna, G., \& Convertino, C. (2013). Are deaf students visual learners? Learning and individual differences, 25, 156-162. doi: 10.1016/j.lindif.2013.02.006 
20. Masataka, N. (2006). Differences in arithmetic subtraction of no symbolic numerosities by deaf and hearing adults. Journal of deaf studies and deaf education, 11(2), 139-43. doi: https://doi.org/10.1093/deafed/enj016

21. Matute, E., Chamorro, Y., Gonzalez, A., Ventura, L., \& Parra, J. (June 2018). EL-A, evaluación de la lectura en adultos [EL-A, evaluation of reading in adults]. XI Conference Cerebro y mente, Tijuana, México (Conference cancelled).

22. Moreno-Pérez, F. J., Saldana, D., \& Rodríguez-Ortiz, I. R. (2015). Reading efficiency of deaf and hearing people in Spanish. Journal of deaf studies and deaf education, 20(4), 1-11. doi: 10.1093/deafed/env030

23. Moreta, R., Gaibor, I., \& Barrera, L. (2017). El bienestar psicológico y la satisfacción con la vida como predictores del bienestar social en una muestra de universitarios ecuatorianos. Salud \& Sociedad, 8(2), 172-184. doi: 10.22199/S07187475.2017.0002.00005

24. Moreta-Herrera, R., López-Calle, C., Gordón-Villalba, P., Ortíz-Ochoa, W., \& Gaibor-González, I. (2018). Satisfacción con la Vida, Bienestar Psicológico y Social, como predictores de la salud mental en ecuatorianos [Satisfaction with Life, Psichological and Social Well-Being as predictors of mental health in Ecuatorians]. Actualidades en psicología, 32(134), 111-125. doi: https://doi.org/10.15517/ap.v32i124.31989

25. Mousley, K., \& Kelly, R. (2017). Developing deaf students fraction skills requires understanding magnitude and whole number division. Journal of education and learning, 7(2), 12-20. doi: 10.5539/jel.v7n2p12

26. Myklebust, H. R. (1971). Psicología del sordo [Psychology of deaf individuals]. Spain: Spanish Magistery.

27. Okada, R., Nakagawa, J., Takahashi, M., Kanaka, N., Fukamauchi, F., Watanabe, K... Matsuda, T. (2015). The deaf utilizes phonological representations in visually presented verbal memory tasks. Neuroscience research, 90, 83-89. doi: https://doi.org/10.1016/j.neures.2014.11.004

28. Padrós, F. G., \& Medina, M. A. (2015). Propiedades psicométricas de la escala de satisfacción con la vida (SWLS) de Diener en población de michoacana (México) [Psychometric properties of the Diener's satisfaction life in Michoacan population]. Avances en psicología latinoamericana, 33(2), 223-232. doi: https://doi.org/10.12804/apl33.02.2015.04

29. Pagliaro, C. M., \& Ansell, E. (2012). Deaf and hard of hearing students' problem-solving strategies with signed arithmetic story problems. American annals of the deaf, 156(5), 438-458. doi: 10.1353/aad.2012.1600

30. Prada, M. F., \& Rucci, G. (2016). Instrumentos para la medición de las habilidades de la fuerza de trabajo [Instruments for the measurement of abilities of the labour force] (Report No. IDBTN-1070). Banco Interamericano de Desarrollo. Retrieved December 05, 2020 from https://publications.iadb.org/publications/spanish/document/Instrumentos-para-la-medición-delas-habilidades-de-la-fuerza-de-trabajo.pdf

31. Wauters, L. N., Van Bon, W. H. J., \& Tellings, A. E. J. M. (2006). Reading comprehension of Dutch deaf children. Reading and writing, 19(1), 49-76. doi: 10.1007/s11145-004-5894-0

32. Wiklunda, J., Nikolaevb, N., Shirc, N., Food, M., \& Bradleye, S. (2019). Entrepreneurship and well-being: past, present, and future. Journal of business venturing, 34(4), 579-588. doi: https://doi.org/10.1016/j.jbusvent.2019.01.002

33. Zubieta, E. M., \& Delfino, G. I. (2010). Satisfacción Con La Vida, Bienestar Psicológico Y Bienestar Social En Estudiantes Universitarios De Buenos Aires [Satisfaction with Life, Psychological and Social Well-being in students in Buenos Aires]. Anuario de Investigaciones, 17, 277-283. Retrieved December 12, 2020 from https://www.redalyc.org/articulo.oa?id=369139946018

34. ***OECD (2013). Literacy, Numeracy, and Problem-Solving in Technology-Rich Environments: Framework for the OECD Survey of adult skills. OECD Publishing. Retrieved March 13, 2020 
from https://www.oecd-ilibrary.org/education/literacy-numeracy-and-problem-solving-intechnology-rich-environments_9789264128859-en

35. ***OECD (2013). PIAAC Programa internacional para la evaluación de las competencias de la población adulta [PIAAC International program for the evaluation of the competences in adult populations]. España: Ministerio de Educación, Cultura y Deporte. Retrieved April 21, 2020 from http://www.oecd.org/centrodemexico/publicaciones/PIAAC\%20Latin\%20America\%20Brochure $\% 20$ Spanish\%20-.pdf

36. ***OECD (2018). PISA Results. Retrieved December 27, 2020 from https://www.oecd.org/pisa/Combined_Executive_Summaries_PISA_2018.pdf

37. ***OECD (2019). OECD Future of Education and Skills 2030. Retrieved June, 2020 from https://www.oecd.org/education/2030project/contact/OECD_Learning_Compass_2030_Concept_Note_Series.pdf

38. ***World Health Organization (2020). Deafness and hearing loss. Retrieved March 13, 2020 from http://www.who.int/mediacentre/factsheets/fs300/en/ 